\title{
A Contrastive Analysis of Hungarian and Croatian Idioms Containing the Component Head*
}

\author{
NINA SPICIJARIĆ PAŠKVAN \\ Croatian Academy of Sciences and Arts, Gjure Ružića 5, HR-51000 Rijeka \\ E-mail: nspicijaric@hazu.hr
}

(Received: 9 June 2018; accepted: 18 September 2018)

\begin{abstract}
This paper analyzes selected examples of idioms containing the component head in Croatian and Hungarian. Despite the fact that Hungarian and Croatian are not cognate languages, due to the universal experiences and to the fact that they belong to a common cultural circle, these languages have a large correspondence in their phraseology, which can be seen in somatic idioms as body parts represent a kind of universality. The aim of this paper is to show similarities and differences in lexical content and meaning of Croatian and Hungarian idioms containing the component head. The motivational basis of idioms is also discussed as well as the influence of basic and transferred meanings of the lexeme head on the meaning of idioms.
\end{abstract}

Keywords: Croatian, Hungarian, contrastive analysis, phraseology, somatic idioms, head

\section{Introduction}

The Croatian essayist, translator, and linguist Tomislav Ladan noted: "The body is something special, beautiful, unique, unrepeatable. Through the body we exist in the world and around the world, we get to know the world, and - ultimately through the body we possess the world, not only the immediate world but the farther one as well" (LADAN 2006: 684).

It is known that somatic idioms belong to the group of the most frequent types of idioms. The frequent use of those idioms is to be expected since the human body is the primary source of human experience and human understanding of the world, and precisely for that reason, humans use the body to acquire knowledge and get their impressions of the world. Thus, the compatibility of somatic idioms in the different languages is a result of the same perception of the human body rather than of direct borrowing caused by cultural and linguistic contact.

Idioms - unlike free combination of words - are defined as fixed structures whose meaning does not follow from the individual meanings of its components (Kövecses-Szabó 1996, Fernando 1996, Menac 2007). They do not occur in the communication process, thus the speaker does not choose the components but the fixed phrase (cf. Menac 2007). The idiom's structure is mostly stable, hence it is characterized by compositeness and fixity, or relative fixity of the components that constitute the idioms in question.

* This paper has been written within the project Internal borrowing in the Croatian language (Unutrašnje posuđivanje u hrvatskome jeziku) financed by the University of Rijeka, Croatia. 
This paper aims to make a contribution to contrastive analysis on the semantic level and to show similarities and differences between idioms containing the component head in Hungarian and Croatian. Selected idioms containing the component head will be analyzed in terms of their motivational basis regarding the basic meaning of the component head or its transferred meanings as well as gestures, conventional knowledge about the head and its symbolism.

Despite the fact that Hungarian and Croatian are not cognate languages, it is assumed that the similarities will prevail due to the universal experiences, particularly evident in somatic idioms. This analysis has been developed on the basis of available Croatian and Hungarian general and idiomatic dictionaries, and has been subsequently confirmed through a survey of native speakers of both languages.

It should be noted that due to the fact that Hungarian and Croatian are not typologically and genetically cognate languages (Hungarian is an agglutinative language belonging to the Uralic family, whereas Croatian is an inflectional language belonging to the Indo-European family), the syntactic structure of idioms will not be reviewed in detail. Therefore, the widely diverse case systems and verb tenses of the two languages will not be taken into account. Translations of idioms will be written in the infinitive form, as it is common in most European languages, though in Hungarian the third person singular is used as lemma.

\section{A contrastive analysis of selected idioms}

The head is mostly considered as the main part of the body where the brain, senses (eyes - sight, ears - hearing, nose - smell, tongue - taste), and initial parts of the digestive (mouth) and respiratory (nose) system are located. The basic meaning of the lexeme head is 'the upper part of the human or animal body' and its transferred meanings include 'the centre of the mind, intellect, thought, memory, understanding, and emotional control' (e.g. prazna glava; üres fej), 'a person, an individual' (e.g. 100 dolara po glavi; 100 dollárt fejenként), 'a position of leadership, command, authority' (e.g. glava obitelji; családfó), 'sth resembling a head in form or function' (e.g. glava kupusa; egy fej káposzta), 'the part of anything that forms the top, summit, or upper end' (e.g. glava čavla; a szeg feje), 'one side of the coin' (i.e. pismo ili glava; fej vagy írás), etc. (HJP, MÉK, DIC).

As the centre of human's intellectual and emotional activity, the head is considered to be the most important part of the human body, largely determining human life. Idioms containing the component head in Hungarian and Croatian are motivated by general conventional knowledge about the head and its symbolism. ${ }^{1}$

\footnotetext{
${ }^{1}$ Examples of idioms in this paper are noted according to the following rules: a slash is used for indicating alternatives (e.g. alternative tenses, alternative verbs, completeness / incompleteness of the action in Croatian, sb/sth, etc.); angle brackets mean that a certain word can be omitted, round brackets indicate the lexical variants in the idiom, and square brackets indicate pronouns. For the purposes of preciseness and accuracy, some of the idiomatic images have been given in their literal meaning and marked by an asterisk.
} 
1. One of the transferred meanings of the lexeme head in its phraseological surrounding is 'a person, an individual'. The first absolutely equivalent idiom in Hungarian and Croatian derives from the Latin phrase per capita meaning 'for each person, per person': Hung. fejenként $;{ }^{2}$ Cr. po glavi.

The component head is also present in the Hungarian idiom a fejét (rá)adja [vmire] meaning 'to accept the job with great passion', which semantically corresponds to a completely non-equivalent idiom in Croatian which does not contain the component head: baciti / bacati se na posao. The second variant of the abovementioned Hungarian idiom ráadja magát [vmire] confirms that the component head metonymically stands for 'a person'. The same metonymy is found only in Hungarian - beszél [vkinek] a fejével with the idiomatic meaning 'to criticize; to berate sb; or to try to reason with sb'. Croatian idioms with completely different motivational basis dovesti (prizvati) $<k>$ pameti $[k o g a]$; prosvijetliti pamet $[k o m u]$; privesti/privoditi $k$ svijesti $[\mathrm{koga}]$; spustiti na zemlju [koga] meaning 'to reason with $s b$; to help sb to behave reasonably; or to open sb's eyes' are semantically close to it.

2. Since the head implies the meaning of 'a vital part of the body', there are a larger number of examples in both languages in which component head metonymically stands for 'life'. Thus, for the 'endangering; facing <mortal $>$ danger; running a risk' completely equivalent idioms are used: Hung. a fejével játszik or Cr. igrati se glavom (in both cases, the component head can be substituted by the lexeme life: Hung. az életével játszik; Cr. igrati se životom). A similar motivational basis is also found in Cr. staviti/stavljati glavu (život) na kocku and Hung. feje (élete) forog kockán and expresses that 'sb's life is in the state of danger', as does the Croatian idiom glava je u torbi [komu]. This group of idioms contains the motivational basis of gambling, expressing that human existence and power depend on luck. In addition, the idiomatic meaning of the expression glava je u torbi [ko$m u$ ] can be explained by the fact that if the head is literally in the bag, one does not see anything and acts blindly, i.e. runs risks. The similar meaning to the previous group of idioms is found in Croatian idiom staviti glavu na panj, even though this idiom is motivated by one of the former execution methods - beheading.

In Hungarian and Croatian, partially equivalent idioms are used to denote 'a secure person, a person convinced of sth, a person who guarantees sth': Hung. a fejemet teszem rá! (a fejét teszi [vmire]) and Cr. dati glavu $<[z a \mathrm{koga}] /[\mathrm{za}$ što] $>$. While the Hungarian idiom contains the verb (rá)tesz 'to put', the Croatian one has the verb dati 'to give'. On the level of semantics, an equivalent in Hungarian would be a fejével felel [vmiért] (garantál), which has different lexical components but the same motivational basis. This group of idioms, which expresses certainty, a guarantee for $\mathrm{sb} / \mathrm{sth}$, is motivated by the fact that in the past people were punished by decapitation, either because they had committed a crime or failed to comply with duties / obligations.

${ }^{2}$ Due to the fact that Hungarian is an agglutinative language, a certain number of Hungarian expressions have a complex internal structure (i.e. they constitute complex idiomatic compounds). 
3. As has been shown above, the component head metonymically stands for 'life', and is therefore present in a number of idioms that denote death and dying (cf. OpAšić-Gregorović 2010). One of such idioms found in both languages in almost identical form is the Hung. a fejébe kerül [vmi] (or az életébe kerül [vmi]) and Cr. stajati (koštati) glave [koga što], meaning 'sb could get hurt, sb could die' (cf. Eng. to cost one one's head). The Croatian idiom platiti glavom (životom) [što] and the Hungarian idiom a fejével lakol [vmiért] also have the same motivational basis as the aforementioned idioms meaning 'to lose life, to die because of sth'.

Furthermore, idioms containing the component head but with different lexical components are used in both languages to express that $s b$ ' 1 . requires sb's death'; 2. 'requires sb's resignation (punishment)', or 3. 'wants to punish $\mathrm{sb}<$ severely $>$ ' Hung. díjat tüz ki [vkinek] a fejére and Cr. tražiti [čiju] glavu. However, while the Hungarian idiom focuses on offering a reward for sb's head, the Croatian idiom expresses the image of demanding sb's head. These idioms are motivated by conventional knowledge of a past practice of political authorities putting up announcements offering a reward for the capture of dangerous criminals (either for their arrest or bringing their head) or demanding sb's head as a proof of their death.

The next series of idioms meaning 'to kill (destroy, ruin) sb' are motivated by the image of a bullet (or in Hungarian, also a piece of lead) that is thrown at sb's head or brain: Hung. golyót (ólmot) repit (röpít) a fejébe (az agyába) and Cr. prosvirati metak kroz glavu (mozak). ${ }^{3}$ In both languages, the component head can be substituted by the component brain. In addition, the Hungarian idiom fejbe lövi magát is used to denote taking one's own life.

4. Furthermore, it is common to perceive the head (i.e. brain) as a centre of one's cognitive abilities. Thus, in a number of idioms, the component head symbolizes intellect and the mind, i.e. their functions: control, rationality, and mental ability. Consequently, a large number of Hungarian and Croatian idioms containing the component head express thinking: the main function of the brain. Completely equivalent idioms with the meaning of 'sb thinking' can be found in both Hungarian and Croatian: Cr. koristiti glavu and Hung. használja a fejét as well as with the meaning of sb thinking independently: Hung. a maga (a saját) fejével gondolkodik or Cr. misliti (razmišljati) svojom (vlastitom) glavom. An image of a person using his/her head for thinking is found in these idioms. The same analogy can be found in idioms expressing thinking that is influenced by others: Cr. misliti (razmišljati) tuđom glavom and Hung. más fejével gondolkozik. In both cases, the head metonymically stands for the 'brain'.

Moreover, in the Hungarian language, the idiom tiszta fejjel gondolkodik is used to denote that a person 'is thinking rationally and objectively' whereas a pair of completely correspondent idioms is used both in Hungarian and Croatian: Hung. hideg fejjel (fövel) and Cr. hladne glave with the image of a cool head (in Hungarian, also the image of a clean head) to express a 'calm, concentrated, focused, rational and wise thought'.

\footnotetext{
${ }^{3}$ The other Croatian variants with the component head and the same meaning include prosvirati glavu $[\mathrm{komu}]$ and prosvirati (prosuti) mozak $[\mathrm{komu}]$.
} 
If the emphasis is placed on the intensity of thinking, the following analogical idioms are used in both Hungarian and Croatian: Cr. motati se (vrzmati se) po glavi [komu što] and Hung. a fejében forgat [vmit], mindig ez (az) jár [vkinek] a fejében. Also, for the idiomatic meaning of 'thinking intensely' in both languages equivalent idioms with the image of *crashing the head because of intensive thinking are used; namely, Hung. töri a fejét [vmin] and Cr. razbijati $<$ sebi (si)> glavu. However, in Croatian, besides the verb razbijati 'to break, to crash', the verbs lupati 'to hit' and trti 'to rub' can be alternatively used. In this context, the Hungarian idiom töri a fejét [vmiben] (rosszban töri a fejét) also has to be mentioned because it has the same components but uses different case government (inessive case, instead of superessive found in the previous example). However, this idiom has a negative connotation, meaning 'to want to do sth bad, to plan how to hurt $\mathrm{sb}^{\prime}{ }^{4}$ Thus, it is evident that in some cases the different case government in Hungarian can imply different connotation.

If thinking is even more intensive, i.e. a person 'becomes concerned about $\mathrm{sb} / \mathrm{sth}$ ' or 'preoccupied with sth', the following idioms are used in Hungarian: $f$ " (füstöl) [vkinek] a feje $<[v k i] /[v m i]$ miatt $>$ or $<[v m i b e n]>$. The image of smoke coming out of one's head because of the intensity of thinking is depicted in these idioms.

Furthermore, the Hungarian idiom szeget (szöget) üt [vkinek] a fejébe is used to denote a cause for sb's doubt as well as an encouragement for sb to engage in thinking. In Croatian, on the other hand, an encouragement to engage in thinking is expressed by the idiom staviti (baciti) bubu (buhu) u uho [komu]. Both idioms contain an image of sth (a nail/an insect, a bug) that does not naturally "belong" to the head, i.e. ear.

The idiom po svojoj glavi is used in Croatian to denote that 'sb acts according to his / her knowledge and will', while the Hungarian idiom with resembling content a maga (a saját) feje után megy (cselekszik) paints an image of a stubborn person who acts without considering another people's opinion.

5. The head as a symbol of the mind and intellect has motivated also the formation of the following group of idioms. In its affirmative form, these idioms refer to one's calmness, control, and rationality, whereas its negative form expresses one's confusion and distraction. Therefore, confusion, distraction, and even panic is expressed by the image of a person without a head, which can be found in the following idioms: Cr. kao bez glave (trčati, motati se, etc.) and Hung. fejetlenül (rohan). On the other hand, the Croatian idiom bez glave, in addition to evoking the image of an excessively confused and distracted person, has also developed its secondary meaning 'to be without a leader, without a guide'. Here, the head symbolizes leadership and not the mind. ${ }^{5}$

\footnotetext{
${ }^{4}$ The idiomatic meaning of causing concerns, troubles, and inconveniences to sb in Hungarian is expressed by the idiom bajt hoz (idéz / zúdit) [vkinek] a fejére.

${ }^{5}$ This last meaning corresponds to Hungarian and Croatian idioms in which the component head stands for 'a leader, a chief' (Hung. [vminek] a feje: államfó; családfó; Cr. glava [čega]: glava obitelji).
} 
Furthermore, when a person is too busy, he/she loses rationality and control of his / her actions, and therefore, this evokes the image of a person who does not know where his/her head is. Such an image is evoked by equivalent idioms in both languages, Hung. azt se ( $m)$ tudja, hol (áll) a feje and Cr. ne znati gdje je glava [komu]. Besides the image of an excessively busy person who has lost his/her presence of mind and control, this idiom can also denote a person who worries too much. Apart from being excessively occupied, the rationality and presence of mind can also be lost if a person is very much in love, which can also result in confusion. That is expressed by equivalent idioms in Hungarian and Croatian, containing the image of a person who has lost his/her head: Hung. elveszti a fejét or fejét veszti and Cr. (iz)gubiti glavu (in the Croatian idiom, besides the component head, alternative components pamet 'mind' and razum 'reason' can also be used). In Hungarian, there is an antonymic idiom nem veszti el a fejét meaning 'to keep calmness and presence of the mind'. On the other hand, the Croatian idiom izgubiti glavu except for the meaning 'to get confused; to lose calmness and presence of mind', also has the meaning 'to die', and in this case, the component head metonymically stands for 'life' (Cr. izgubiti glavu = izgubiti život). A person in love sometimes acts irrationally and crazy because of the influence that sb has on his/her behaviour. This is expressed by the following equivalent idioms in both languages: Cr. zavrtjeti glavom (glavu) [komu], Hung. elcsavarja [vkinek]> a fejét (cf. Eng. to turn one's head) meaning 'to affect the emotional stability of sb, to fascinate $\mathrm{sb}$, to seduce sb'. Besides falling in love with, glory can also result in a change of a person's behaviour. This is also expressed by the image of sth turning one's head. In other words, if a person turns sb's head, one becomes confused and distracted, and if glory turns sb's head, one becomes self-conceited, vane, and self-important (cf. Cr. udarilo je u glavu [komu što]; Hung. fejébe száll a dicsöség).

As the centre of mental abilities and brain activity, the lexeme head again motivates completely correspondent idioms in Hungarian and Croatian: Hung. fejben kiszámol [vmit] and Cr. računati (brojati) u glavi [što] meaning 'to do mental arithmetic'. Equivalent idioms are used in both languages to express the idiomatic meaning 'to speak or know sth by heart or according to memory': Hung. fejböl $<$ tud [vmit] $>$ and Cr. iz glave < govoriti /znati $[\check{\text { sto }}]>$. The image of *having sth in one's head, evoked by the following Hungarian and Croatian idioms van [vkinek] a fejében [vmi] and imati $<$ malo više $>$ u glavi, describes a smart person. In addition to the idioms analyzed above, the Croatian idioms imati mozga $<u$ glavi $>$ (*to have brain $<$ in the head $>$ ) and imati soli $u$ glavi (*to have salt in the head) can be used to describe a person who is 'clever, bright, and quick-witted'. In the latter, salt stands as a symbol of important, valuable, and indispensable food (if a person lacks salt in the head, it means that he/she actually lacks sth essential that would enable a normal brain function). ${ }^{6}$ It can be concluded that the existence of a particular content in the head is an indication that a person has developed an ability to think, which makes them smart and intelligent.

\footnotetext{
${ }^{6}$ Interestingly enough, the image of salt as an important food supplement is replaced by oil in a semantically correspondent idiom in Polish: mieć olej w głowie (SPAGIŃSKA-PRUSZAK 2001). 
6. In the following group of idioms, one of the basic functions of the brain, memorizing is expressed. Thus, the idiomatic meaning 'to remember sth' can be depicted by the Croatian idiom držati (imati) u glavi [što] as well as the Hungarian equivalent idiom fejben tart [vmit]. The Hungarian and Croatian idioms tele van [vkinek] a feje [vkivel] / [vmivel] and puna je glava [komu čega] denote a person that constantly thinks about sth or is preoccupied with problems or work. On the other hand, idioms reflecting the antonymic image of an empty and hollow head (Hung. üres fej; Cr. prazna/šuplja glava) express a completely different meaning: they paint a picture of a stupid and foolish person. In addition, equivalent idioms are used to describe a 'stupid and narrow-minded person' in both Hungarian and Croatian: Hung. huzatos [vkinek] a feje; Cr. imati propuh u glavi. In the previous idioms, the image of draft is evident, which is possible only in empty spaces.

To describe a person with dull mental responses and low intelligence, the Croatian idiom imati tvrdu glavu is used. In addition, the Croatian adjective tvrd 'firm, solid' also means 'stubborn, obstinate'; hence, the above-mentioned idiom evokes an image of a solid, thick head (KovAČEVIĆ 2012). The same meaning is expressed by the compound firm + head, which can be found in both Hungarian and Croatian (Hung. keményfejü; Cr. tvrdoglav and [tko] je tvrde glave).

Besides the ability of the mind to remember and recall past knowledge and experiences reflected in the idioms Cr. držati (imati) u glavi [što] and Hung. fejben tart [vmit] (*to keep sth in a head), the human brain is also responsible for forgetting things, either consciously or unconsciously. In this respect, the idiomatic meaning 'to forget $\mathrm{sb} / \mathrm{sth}$; to stop thinking of $\mathrm{sb} / \mathrm{sth}$ ' is expressed by equivalent idioms in Hungarian: kimegy (kipárolog / kirepül / kiesik) [vkinek] a fejéböl [vmi] and in Croatian: izaći/izlaziti iz glave. On the other hand, the antonymic idioms Cr. ne ide (izlazi) iz glave [komu što] and Hung. nem megy ki a fejéböl suggest the impossibility of a person to forget $\mathrm{sb} / \mathrm{sth}$. Their explicitly antonymic idioms (containing the antonymic components from - to: Cr. $u-i z$; Hung. -ba/-be--ból/ -böl) include Hung. nem megy [vkinek] a fejébe [vmi] and Cr. ne ide u glavu [komu $\check{s} t o$ ]. Yet, their idiomatic meaning is not related to memory but to lack of strength or ability to understand a certain, often bizarre situation. ${ }^{7}$ In addition, when a person 'consciously wants to forget $\mathrm{sb} / \mathrm{sth}$ ' or 'deliberately wants to stop thinking of $\mathrm{sb} / \mathrm{sth}$ ' the idioms Hung. kiver a fejéböl $[v k i t] /[v m i t]$ and Cr. izbiti $<$ sebi $($ si $)>i z$ glave $[\mathrm{koga}] /[$ što $]$ or Cr. izbaciti iz glave (pameti) $[\mathrm{koga}] /[$ što] are used (*to kick out $\mathrm{sb} / \mathrm{sth}$ from the head).

7. In Hungarian, the idiomatic meaning of 'a clever and capable person' is expressed by the idiom nem ejtették a feje lágyára [vkit] or nem esett a feje lágyára (a fejére). Antonymic idioms denoting a person who 'lost his/her mind, is dull and slow-witted' include Hung. a fejére esett (ejtették) [vkit] and Cr. pasti na glavu. Furthermore, the Croatian idiom udaren u glavu (mozak) is used to denote that ' $s b$ is foolish, queer, and odd from a conventional viewpoint'. These idioms are motivated by the conventional notion that if a person is hit in the head, if some-

${ }^{7}$ The Hungarian idiom with the verb fér 'to fit in sth', i.e. nem fér 'not to fit in sth', nem fér [vkinek] a fejébe [vmi] is semantically equivalent to it. 
one falls on the head or if a baby's skull is damaged, their mental abilities might also suffer damage.

The following idioms are used to describe a smart person: Hung. világos fej and Cr. bistra glava. The Croatian idiom bistra glava (*bright, clear head) is also related to the Croatian idiom razbistriti glavu, which evokes the idiomatic image of rendering one's head clearer or sharpening one's focus. Thus, a person can think, reason, and act in a smarter and cleverer way. In Hungarian, in addition to világos fej, the idiom jó feje van is also used to describe a smart person who learns fast.

8. The idiomatic meaning 'to cause sb to worry, or to cause sb troubles' is expressed both in Hungarian and Croatian by equivalent idioms which do not contain the component head as a free morpheme but its compound headache: Hung. $<$ sok> fejtörést (fejfájást) okoz [vkinek] [vki]/[vmi], and Cr. zadati/zadavati glavobolje [komu]. Thus, a person gets a headache as a result of problems, concerns or great exposure to suffering. The image of headache is also used to denote that $\mathrm{sb}$ has worries, and in this regard, equivalent Hungarian and Croatian idioms are used: Hung. fáj vkinek a feje [vki miatt] / [vmi miatt] or [vkitöl]/[vmitöl] and Cr. boli glava [koga] [zbog koga]/[zbog čega] or [od koga]/[od čega]. However, this idiom in its negative form means 'not to care for sb/sth; to be indifferent to $\mathrm{sb} / \mathrm{sth}$ ': Hung. nem fáj [vkinek] a feje [vki miatt] / [vmi miatt]; Cr. ne boli glava [koga] [za koga]/[za što].

The idiomatic meaning 'to decide sth' is expressed by the Hungarian idiom a fejébe vesz [vmit]. The Croatian idiom utuviti (uvrtjeti, zabiti) <sebi (si)> u glavu [što], being slightly stronger than its Hungarian counterpart, means 'to decide sth firmly, to persistently want sth, to be obsessed with a thought'. Both idioms contain the image of putting sth in one's head, and it can be said that the Hungarian idiom is neutral, while the Croatian one expresses persistence in that decision (reflected also by the verbs contained in the Croatian verb 'to inculcate sth in sb').

9. The following idioms are used with the meaning 'to be preoccupied with sth (e.g. work, worries)' in Hungarian and Croatian: Hung. a feje búbjáig tele van [vmivel] and Cr. imati preko glave [čega] (cf. Eng. up to one's ears / eyeballs / eyes in sth). Besides denoting a person's excessive preoccupation with sth, both idioms can also express 'sb having enough of sth; sb being bored with sth; or sth being unbearable to sb'. Thus, the idioms Hung. a fejére nö [vkinek] or Cr. popeti se na glavu (navrh glave) [komu], and Cr. navrh glave je [koga]/[čega] [komu] also indicate a person on the edge of tolerance, patience, and endurance, expressed by the image of $\mathrm{sb} / \mathrm{sth}$ being / getting on the top of the one's head. This could be explained by the fact that the head represents the upper limit of the human body either literally or metaphorically.

10. One of the most common emotions is anger, so there is a whole group of idioms expressing anger. Two completely equivalent idioms in Hungarian and Croatian contain the image of a person whose blood pressure is high because of irritation and anger, resulting in more blood flowing into their cheeks: Hung. a vér [vkinek] a fejébe tódul; Cr. udarila (jurnula) je krv u glavu [komu] 'sb is upset, agitated with blushing cheeks because of anger'. In addition, anger can be expressed 
by the Hungarian idiom a fejét veszi [vkinek] and two other (only partially equivalent) idioms in the two languages: Hung. leharapja [vkinek] a fejét and Cr. skinuti/skidati glavu [komu] (cf. Eng. bite sb's head off). These last examples reflect the image of biting or snapping one's head off, with the meaning of punishing sb; both are based on the conceptual knowledge of punishment by decapitation.

Reprimand, criticism, and complaint based on the concept of physical abuse as a form of punishment are expressed by equivalent idioms in both languages: Hung. kap egyet a fejére and Cr. dobiti po glavi. ${ }^{8}$ Moreover, a severe reproof or reprimand of sb who has made a mistake can also be expressed by the image of *washing sb's head. This image can be found in two entirely equivalent idioms in Hungarian and Croatian: megmossa [vkinek] a fejét and oprati / prati glavu [komu]. ${ }^{9}$

Reproach, on the other hand, can be expressed by the image of hitting and throwing sth in sb's head: Hung. [vkinek] a fejéhez vág [vmit] 'to tell openly and roughly sth to sb (cf. Eng. to tell sth to sb's face; Cr. reći u lice [komu što])' and with the image of *reading to sb's head: fejére olvas [vmit] [vkinek] 'to tell openly one's mistakes; to berate sb'. ${ }^{10}$

The idiomatic meaning of having an unclear conscience is reflected in two entirely equivalent Hungarian and Croatian idioms: Cr. imati putra na glavi and Hung. vaj van [vkinek] a fején. These idioms probably arise from the Austrian or Bavarian proverb Wer Butter auf dem Kopf hat, soll nicht in die Sonne gehen. ${ }^{11}$ This proverb can be explained by the fact that in the past peasant girls used to go to the marketplace with a basket on their head containing butter and other products to be sold. If they happened to be walking in the sun for too long, or to stop for some reason, the butter would melt and pour over their heads. The melted butter would have shown their recklessness, negligence and guilt, and thus, it has acquired a negative connotation (KEBER 2011).

The following Hungarian and Croatian idioms contain the image of sth hitting sb's head or fall onto it, resulting in a change in a person's behaviour. In that manner, the Croatian idiom udarilo je u glavu [komu što] denotes a person '1. getting drunk or being under the influence of alcohol' or '2 2 . being conceited and self-important', as do the Hungarian idioms: a fejébe száll a bor (az ital) / a fejébe száll a dicsöség. In other words, if literally speaking, alcohol hits one in the head, one becomes drunk, and if glory hits one in the head, one becomes self-conceited and self-important.

11. The following two idioms, which will be subjected to our analysis, are idioms motivated by gestures. The first example expresses regret and remorse,

\footnotetext{
${ }^{8}$ The semantically equivalent idioms include: Cr. dobiti po prstima; dobiti po repu; dobiti po gubici (njušci/zubima/nosu) and Hung. fejmosásban részesül; fejmosást kap.

${ }^{9}$ A partially equivalent image is also found in Hung. fejmosásban részesit [vkit]; Cr. oprati/ prati uši [komu]; nasapunati/sapunati glavu [komu]; natrljati/trljati (obrisati/brisati) nos [komu].

${ }^{10}$ The Croatian idioms nabiti/nabijati (objesiti/vješati) na nos [komu što] $(\approx$ a fejéhez vág [vkinek vmit]) and očitati/čitati (održati/držati) bukvicu $[$ komu] ( $\approx$ fejére olvas [vmit vkinek]) without the component head are semantically equivalent to them.

${ }^{11}$ An equivalent Hungarian proverb is: Akinek vaj van a fején, ne menjen a napra.
} 
evoking the image of a person who puts his/her hands on the head because of the mistakes made. It is expressed by entirely equivalent idioms in Hungarian (fogja a fejét) and Croatian (uhvatiti se/hvatati se za glavu).

Next to be analyzed are some completely equivalent Hungarian and Croatian idioms also motivated by the gestures. They express the image of a person holding his / her head up and refer to a proud person who walks through life with self-confidence and self-reliance: Hung. emelt fejjel (fövel) or felemelt fejjel (fóvel) and Cr. uzdignute glave (čela). The same image motivated also the Croatian idiom dignuti/dizati glavu meaning 'to become more self-confident' and completely equivalent idioms Hung. fel a fejjel $<!>$ and Cr. glavu gore $<!>$ used for expressing encouragement: 'don't lose courage $<$ ! $>$, don't be sad $<$ !' '. Contrary to self-awareness and pride stand humility and submission. These states are expressed by Hung. fejet (térdet) hajt [vki elött] and Cr.pognuti glavu (šiju) [pred kim]. In these examples, the second Hungarian variant contains an image of sb kneeling down in front of another person, whereas the first as well as the Croatian idiom represents a person bowing. The other Croatian variant contains an image of bending one's šija 'neck' in front of $\mathrm{sb}$. With the gesture of bowing, a person hides his/her face in order to hide his/her embarrassment and humiliation. The same motivation is found in the Hungarian idioms lóg [vkinek] a feje or lógatja a fejét, with an image of a person whose head is hanging down, thus denoting his/her state of depression, sadness, and desperation. The idioms analyzed above are motivated by gestures involving head movements (cf. HRNJAK 2005).

12. Furthermore, equivalent idioms are used in Hungarian and Croatian to express a person 'deliberately ignoring the truth, reluctant to face an uncomfortable reality or closing his/her eyes to facts': Hung. homokba dugja a fejét (beledugja a fejét a homokba), mint a strucc and Cr. gurnuti/gurati (zabiti/zabijati) glavu $u$ pijesak <kao noj>. In Croatian, the component kao noj is optional, while in Hungarian, the first part of the idiom is optional and can be substituted by úgy tesz, mint a strucc. According to the myth, an ostrich hides its head into the sand when the predators are coming closer. In that way, an ostrich avoids the predators, just as a man sometimes willingly ignores the harsh truth and reality. It is scientifically proved that this theory isn't true but there are many behaviours of ostriches that might have resulted in generating this myth. ${ }^{12}$ Ignoring the true is also expressed by the entirely equivalent Hungarian and Croatian idioms containing the image of a person turning his/her head to the other side: Hung. elforditja a fejét and Cr. okrenuti/okretati glavu [od koga/od čega] meaning 'to ignore sb/sth; not to pay attention to sb/sth' motivated by the logic that if one does not see it, it does not really exist.

13. The state of poverty is expressed by the following Hungarian and Croatian idioms: Hung. nincs fedél [vkinek] a feje fölött (and the antonymic van fedél

\footnotetext{
${ }^{12}$ Why do people think that ostriches bury their heads in the sand?, October 7, 2014. https:// wildlifetv.wordpress.com/2014/10/07/why-do-people-think-that-ostriches-bury-their-heads-in-thesand/.
} 
[vkinek] a feje fölött), containing the same idiomatic image as the Croatian idiom biti bez krova nad glavom (and the antonymic imati krov nad glavom). Thus, the phrase a roof over one's head denotes 'one's own home, shelter', while the lack of it indicates poverty. In addition to the above-mentioned idioms, the idiomatic meaning of poverty in Hungarian is also depicted by the image of a person that does not know where to lay his/her head: Hung. nincs hol (hova) a fejét lehajtania. It is motivated by the conventional notion that a house or a bed are the basic prerequisites for a decent living. The same motivation but the different meaning is found in the Hungarian national idiom jól megvetette a feje alját; jó helyre tette (vetette) a feje alját 'to ensure one's own subsistence in the future'.

14. The following idiom is found only in Hungarian: benö [vkinek] a feje lágya, and it has the idiomatic meaning of 'getting serious'. There is also an antonymic idiom in Hungarian: nem nött < még > be [vkinek] a feje lágya meaning 'frivolous, reckless'. These idioms are motivated by the conventional notion of a newborn baby's scull being soft for the first couple of months (BENCZEs 2002). Metaphorically, if a person's scull is still soft, that person is not mature enough. ${ }^{13}$

Next to be analyzed are two Hungarian idioms motivated by wedding customs and traditions. The custom according to which a bride at midnight after the wedding changes her wedding dress, takes off the veil from her loose hair and ties her hair with a scarf is reflected in the idiom beköti [vkinek] a fejét. The second idiom is felteszi a kontyot [vkinek] a fejére or kontyot tesz [vkinek] a fejére, motivated by the Hungarian custom according to which girls wear braids before their marriage, and a chignon after being married. Both idioms mean 'to take a wife'. ${ }^{14}$

15. All of the idioms given in the following section are motivated by one of the meanings of lexeme head being the upper limit of the human body. The image of turning sth on the top of one's head is undoubtedly a symbol of a mass, disorder, aberration and is evoked by the following Hungarian and Croatian idioms: Hung. a feje tetejére állit [vmit $]^{15}$ and Cr. okrenuti/okretati (obrnuti/obrtati) naglavce $^{16}$ (naopako) meaning 'to change sth completely, to make a mess, to turn sth upside down'.

The image of standing on one's own head, in addition to the above-mentioned meaning, can also stand for an attempt to achieve sth impossible or an endeavour to achieve sth unrealistic. This is expressed by the following idioms: Hung. $<m e ́ g>$ ha a feje tetejére áll is and Cr. makar dubio na glavi [tko]; može dubiti na glavi [tko] or makar se na glavu postavio [tko]. ${ }^{17}$ The metaphor of the head as the upper limit of the human body and the heels as its lower limit served as a motivation

${ }^{13}$ Additionally, the English idiom to be soft in the head with the same motivation has developed the idiomatic meaning of a 'person with low mental abilities'.

${ }^{14}$ These explanations were obtained by Mrs. Olga Sarolta Širola.

${ }^{15}$ The same motivational basis is found in the Hungarian idiom a feje tetején áll [vmi] 'sth is in a mess, sth is upside down'.

${ }^{16} \mathrm{Cr}$. naglavce is a compound consisting of the adverb na 'on' and glava 'a head'.

${ }^{17}$ The same meaning can also be expressed with the Croatian idiom makar se na trepavice postavio [tko], with the component eyelashes instead of head. 
for the following Croatian and Hungarian idioms: Cr. od glave do pete (Eng. from head to toe (foot/heels) and Hung. tetötöl talpig, meaning 'thoroughly, through'. These are international idioms, i.e. calques deriving from the Latin phrase a capite $<$ usque> ad calcem found in Bible (cf. OpAšíc 2013: 202, 203).

16. Equivalent idioms are used in Hungarian and Croatian to describe an overly proud person, i.e. a person with excessive self-esteem: Hung. nem esik le a korona [vkinek] a fejéröl [vmitöl] and Cr. neće pasti kruna s glave [komu]. In these idioms, we have the crown symbolism, and since the crown is associated with people who possess power and authority, it metaphorically represents sth that could be potentially lost. Thus, these idioms express that if a person does sth (he / she is asked to do), he/she will not lose anything and his/her dignity will not be harmed (metaphorically, a crown would not fall from his/her head) and he/she will not be worth less because of it.

On the other hand, the Hungarian idiom hagyja, hogy a fején táncoljanak is used to describe an indulgent and excessively lenient person. The same image of dancing on sb's head is also present in Cr. plesati po glavi $[\text { komu }]^{18}$, where the emphasis is on the fact that a person allows others to take advantage of his/her kindness and patience.

17. Finally, the idioms expressing stubbornness and inflexibility ${ }^{19}$ include: Hung. fejjel megy a falnak and Cr. ići glavom kroz (kroza) zid. Both of them contain the motivation of impossibility to pass through the wall, meaning 'trying hard to accomplish sth unattainable or trying to overcome an insurmountable difficulty'. A resembling image is evoked by the Hungarian idiom a falba veri a fejét, and Croatian lupati glavom o zid (cf. Eng. beat one's head against the wall; bang one's head against a brick wall). These idioms, in addition to expressing useless persistence and stubbornness, also develop the meaning of regretting sth and realizing sth a bit too late.

\section{Conclusion}

In the largest number of analyzed idioms, the component head is perceived as a centre of cognitive abilities. Hence, as the head becomes the symbol of reason and intellect, Hungarian and Croatian idioms containing the component head express the ability or the lack of ability to think in a logical and realistic manner. More precisely, human mental abilities or the lack of them have served as a motivation for the largest number of analyzed idioms (e.g. wisdom, decision making, control and rationality, confusion, memory and oblivion, etc.) but many analyzed idioms containing the component head also express different human behaviours and conditions, e.g. work burnout, anger, ignoring reality, punishment and reprimand, regret, poverty, etc.

\footnotetext{
${ }^{18}$ Besides *dancing on sb's head, in Croatian, it can also be said that *sb is jumping on sb's head (Cr. skakati po glavi [komu]).

${ }^{19}$ Expressed also with the already analyzed idioms: Cr. tko je tvrde glave; imati tvrdu glavu.
} 
Furthermore, a large number of Hungarian and Croatian idioms containing the component head are used to describe human character, i.e. to describe a dignified and /or a proud person, a subordinate or an excessively indulgent person, a smart or a dull person, a stubborn person, etc. In a large number of idioms, the component head metonymically stands for 'an individual'. There is also a certain number of analyzed idioms in which the component head metonymically stands for 'life' resulting in a number of idioms expressing the concepts of life and death, i.e. the direct or indirect cause of death, and many of these idioms describe the state of a person put in danger or a person that has already succumbed to it.

The analysis has shown that basic and transferred meanings of head as well as gestures, conventional knowledge about the head, and its symbolism strongly influenced the motivational basis and the meaning of selected Hungarian and Croatian somatic idioms with the component head.

The observations made in this paper have shown a number of similarities between idioms containing the component head in the Hungarian and Croatian language. Thus, many idioms have shown complete equivalence of lexeme components and motivational basis, some of them have shown partial equivalence and similarity of motivational basis, while others have shown discrepancy of lexeme components and lack of correspondence of motivational basis.

\section{References}

ANIĆ 2004 = ANIĆ Vladimir: Veliki rječnik hrvatskoga jezika. Zagreb, 2004.

BÁRDOSI 2012 = BÁRDOSI Vilmos: Magyar szólások, közmondások adatbázisa. Budapest, 2012.

BenCZES 2002 = Benczes Réka: The semantics of idioms: a cognitive linguistic approach.

The Even Yearbook 5 (2002): 17-30.

DIC = Dictionary.com. Oakland, 1995. http://content.dictionary.com.

FERNANDO 1996 = FERNANDO Chitra: Idioms and Idiomaticity. Oxford, 1996.

GULÁCSI 2012 = GULÁCSI Tibor-Sándor: Közmondások tükörben. Arad, 2012.

$\mathrm{HJP}=$ Hrvatski jezični portal. . http://hjp.znanje.hr.

HRNJAK 2005 = HRNJAK Anita: Geste i mimika kao izvor frazeologije (na primjeru hrvatske frazeologije). Filologija 44 (2005): 29-50.

KEBER 2011 = KEBER Janez: Slovar slovenskih frazemov. Ljubljana, 2011.

KoltaY-KASTNER-JuHÁsz 2000 = Koltay-KASTNER Jenö, JUHÁsZ Zsuzsanna: Magyarolasz szótár / Vocabolario ungherese-italiano. Budapest, 2000.

KovAČEviĆ 2012 = KovAČEviĆ Barbara: Hrvatski frazemi od glave do pete. Zagreb, 2012. Kövecses-Szabó 1996 = Kövecses Zoltán, Szabó Péter: Idioms. A View from Cognitive Semantics. Applied Linguistics 17 (1996): 326-355.

LADAN 2006 = LADAN Tomislav: Etymologicon. Zagreb, 2006.

MATEŠIĆ 1982 = MATEŠIĆ Josip: Frazeološki rječnik hrvatskoga ili srpskoga jezika. Zagreb, 1982.

MÉK = JuHÁsz József et al. (szerk.): Magyar értelmezö kéziszótár I-II. Budapest, 2000. Menac 2007 = MenaC Antica: Hrvatska frazeologija. Zagreb, 2007.

MenAC et al. 2003 = MenAC Antica, FinK ARsovsKi Željka, VENTURIN Radomir: Hrvatski frazeološki rječnik. Zagreb, 2003. 
OpAŠIĆ 2013 = OpAŠIĆ Maja: Biblizmi u hrvatskome jeziku. Doctoral thesis. Zagreb, 2013. Opašıć-Gregorović 2010 = OpAŠić Maja, Gregorović Maja: Smrt u hrvatskoj frazeologiji. Croatica et Slavica Iadertina 6 (2010): 55-72.

PALICH 1982 = PALICH Emil: Magyar-szerbhorvát kéziszótár/Priručni mađarsko-srpskohrvatski rječnik. Budapest, 1982.

ŠONJE 2000 = ŠONJE Jure (ured.): Rječnik hrvatskoga jezika. Zagreb, 2000.

SPAgiŃSKA-PRUSZAK 2001 = SPAGIŃSKA-PRUSZAK Agnieszka: Frazemi sa sastavnicom 'glava' kojima se iskazuju intelektualne osobine u hrvatskome, poljskom i ruskom jeziku. In: Drugi hrvatski slavistički kongres. Zbornik radova I. Zagreb, 2001. 635-642.

Teliya et al. 2005 = Teliy A Veronika, Bragina Natalia, OpArinA Elena, SANDOMIRSKAyA Irina: Phraseology as a language of culture. Its role in the representation of a collective mentality. In: CowIE A. P. (ed.) Phraseology. Theory, Analysis and Applications. Oxford, 2005. 55-75. 